\title{
Physicochemical, Antioxidant and Microbial Properties of Fresh Black Stem Sugarcane Juice with Addition of Calamansi Juice
}

(Sifat Fizikokimia, Antioksidan dan Mikrob Jus Tebu Segar Batang Hitam dengan Jus Calamansi)

\author{
NOOR AFIQAH Md NOOR, MAIZURA MURAD* \& EFFARIZAH MOHD ESAH
}

\begin{abstract}
This study was designed to determine the physicochemical, antioxidant and microbial properties of fresh sugarcane juice with calamansi juice addition. The sugarcane that was used in the experiments was the black cane variety (Saccharum officinarum). Sugarcane pressed with and without their peel was juiced and added with calamansi juice before analysis was carried out. Standard method was used to analyse physicochemical properties such as pH, total soluble solids, acidity and colour of sugarcane juice. Total phenolic content (TPC), DPPH and FRAP assay were conducted for antioxidant properties. Total plate count and yeast and mould count were carried out for the microbiological analyses. Two way analysis of variance $($ ANOVA) shows significant $(\mathrm{p}<0.05)$ difference on colour of sugarcane juiced after extraction with and without peel. There were no significant $(\mathrm{p}>0.05)$ difference shown for $\mathrm{pH}$, acidity and total soluble solids of sugarcane juice pressed with and without peel. Sugarcane juice pressed with peel produced higher antioxidant value compared to sugarcane pressed without peel. However, sugarcane juice pressed without peeled showed a lower microbial count compared to sugarcane juice pressed with peel. The addition of calamansi juice proved to have significant $(\mathrm{p}<0.05)$ effect on colour, antioxidant and microbial count of the sugarcane juices.
\end{abstract}

Keywords: Antioxidant; black stem; microbial; physicochemical; sugarcane juice

\section{ABSTRAK}

Kajian ini bertujuan untuk menentukan sifat fizikokimia, antioksidan dan mikrob tebu segar dengan penambahan jus calamansi. Tebu yang digunakan dalam uji kaji ini adalah daripada varieti tebu hitam. Tebu yang diperah dengan dan tanpa dikupas ditambah dengan jus calamansi sebelum analisis dijalankan. Kaedah piawaian telah digunakan untuk menganalisis sifat fizikokimia seperti pH, jumlah pepejal terlarut, keasidan dan warna jus tebu. Jumlah kandungan fenolik (TPC), DPPH dan asai FRAP dijalankan untuk sifat antioksidan. Kiraan jumlah plat dan yis serta kulapuk dijalankan untuk analisis mikrobiologi. Analisis dua hala varians (ANOVA) menunjukkan perbezaan signifikan (p<0.05) pada warna tebu yang diperah dengan dan tanpa dikupas. Tiada perbezaan signifikan ( $\mathrm{p}>0.05$ ) yang ditunjukkan bagi pH, keasidan dan jumlah pepejal terlarut jus tebu yang diperah dengan dan tanpa dikupas. Jus tebu yang diperah tanpa dikupas menghasilkan nilai antioksidan yang lebih tinggi berbanding dengan tebu yang diperah dengan kulit. Walau bagaimanapun, jus tebu yang diperah tanpa dikupas menunjukkan kiraan mikrob yang lebih rendah berbanding jus tebu yang diperah dengan kulit. Penambahan jus calamansi terbukti mempunyai kesan yang signifikan $(\mathrm{p}<0.05)$ terhadap warna, antioksidan dan kiraan mikrob ke atas jus tebu.

Kata kunci: Antioksidan; batang hitam; fizikokimia; jus tebu; mikrob

\section{INTRODUCTION}

In Malaysia, sugarcane (Saccharum officinarum) is found in abundance. Even though there are many species of sugarcanes, the yellow stem variety or locally known as Tebu Kuning is the most popular sugarcane used for juicing. Most of the research conducted focus more on yellow stem sugarcane as it is the most widely grown species across the world (Siti \& Baharuddin 1994). In Malaysia, it has been observed that there has been an increase in sugarcane juice vendors who has been using black stem sugarcane as a substitute for the usual yellow stem. However, to date, there has been very little published information regarding the black stem sugarcanes. A study conducted by Chauhan et al. (2002) discovered that the physicochemical characteristics of sugarcane juice obtained from different varieties differed significantly and the differences in the characteristic of the juices could be due to the variations in the plant composition due to different periods of planting, harvesting times, climatic conditions and also maturation stages (Stone \& Sidel 1985). Hence, it can be said that the characteristic of sugarcane juices may be affected by the type of sugarcane used and also the cultivation practices. Therefore, one of the aims of this study was to determine the physicochemical properties of black stem sugarcane juice.

This local favourite drink is usually sold fresh at night markets and by street vendors without any treatment. However, this sweet and thirst quenching beverage can be 
a health risk to drinkers through pathogens contamination or poor handling practice. Sugarcane juice spoils rapidly even when refrigerated (Yusof et al. 2000) due to its high water activity and sugar content. There have been many efforts done to maintain safety and extend the shelf life of sugarcane juice. This includes reducing the $\mathrm{pH}$ of the juice to below 4.6, which is an important step used to help reduce the juice from microbial spoilage (Kunitake et al. 2014) and subsequently extend the shelf life. There have also been research conducted which applies thermal treatment and acid additions to the sugarcane juice, to help curb the browning effects and increase the shelf life of the juice. For example, different amount of anola juice (Sangeeta et al. 2013), lemon juice and ginger (Khare et al. 2012) as well as ascorbic acid (Mao et al. 2007) were added separately to sugarcane juice in a combination with different extent of thermal treatment to reduce browning by inhibiting enzymatic activities.

Calamansi (Citrus microcarpa) is a species of lime used in Southeast Asia cuisines, especially in Malaysia, Singapore, Indonesia and the Philippines. Calamansi is chosen for this research as it is found to contain phenolic compounds for example caffeic, coumaric acid and sinapic acid which play a role as natural antimicrobial agents (Cheong et al. 2012). It also could reduce the $\mathrm{pH}$ of sugarcane juice and prevent oxidation of phenolic compounds by peroxidase (POD) and polyphenol oxidase (PPO) enzymes. Both are enzymes that cause formation of melanoidin through oxidation of phenolic compounds in the juice (Qudsieh et al. 2002) which causes browning in sugarcane juice. The purpose of this research was designed to study the physicochemical properties such as $\mathrm{pH}$, total soluble solids (TSS), colour, antioxidant and microbiological properties on the sugarcane juices that are pressed with and without its peel. A study will also be conducted to examine if the addition of calamansi juice would have significant effect on the physicochemical, antioxidant and microbial properties measured for the black stem sugarcane juice.

\section{MATERIALS AND METHODS}

The black stem sugarcane was obtained from a sugarcane farm in Merbok, Kedah, Malaysia. Calamansi fruits were purchased from Tesco Extra, Sg. Dua, Penang, Malaysia. Chemicals used such as hydrochloric acid and Folin-Ciocalteu reagent were obtained from R\&M Chemicals (United Kingdom). The Iron (II) sulphate was obtained from Fisher Chemicals (Leicestershire, UK) while 2,2-diphenyl-1-picrylhydrazyl (DPPH) was purchased from Sigma-Aldrich Co. (USA). Gallic acid, 2,4,6-tripyridyl-striazine (TPTZ) and iron(III) chloride hexahydrate were purchased from Merck (Germany) and sodium carbonate was purchased from Bendosen Laboratory Chemicals (Norway). Microbiological media such as Peptone powder, Plate Count Agar and Potato Dextrose Agar were obtained from Merck (Germany).

\section{PREPARATION OF SUGARCANE JUICE}

Sugarcane of the black stem variety was obtained and before the extraction of juice, the stems were washed to remove dirt and debris on the surface. For samples that require the sugarcane peel to be removed, the sugarcane stem was peeled using a hand-held peeler. The juices from the sugarcane stem with and without peel were extracted by using a commercial power crusher and then filtered by using a muslin cloth. Calamansi juice at different concentrations $(0.0 \%, 1.0 \%, 1.5 \%$, and $3.0 \% \mathrm{v} / \mathrm{v}$, respectively) was then added to the fresh sugarcane juice and physicochemical, antioxidant and microbial analyses were conducted.

\section{DETERMINATION OF PH, TOTAL SOLUBLE SOLIDS (TSS) AND TITRATABLE ACIDITY (TA)}

For the determination of $\mathrm{pH}$ values of the sugarcane juices, a digital pH meter (Mettler Toledo Seven Easy pH meter S20-K, Columbus) was used for the test. Before the samples were analysed, the machine was first calibrated using buffers of pH4.0 and 7.0. All measurements were carried out in triplicate.

Total soluble solids (TSS) content of the sugarcane juice was determined by using a digital refractometer (Hanna Instruments 96801 Digital Refractometer, USA). Three drops of sugarcane juice were placed on the refractometer screen and measurements were done at $25^{\circ} \mathrm{C}$ and the values obtained were expressed as ${ }^{0} \mathrm{Brix}$. Calibration of the device was carried out before measurements of the sample and was done using distilled water and all samples were measured in triplicate.

Titratable acidity (TA) was determined using the method described by Sarkar et al. (2015). Potentiometric method was used as sugarcane juice is highly coloured. Ten $\mathrm{mL}$ of sugarcane juice was pipetted into a conical flask and mixed well with $90 \mathrm{~mL}$ of distilled water. The mixture was then titrated with $0.1 \mathrm{~N} \mathrm{NaOH}$ and the end point were obtained when the mixture is at a $\mathrm{pH}$ of 8.1 . The results were expressed as a percentage of citric acid.

\section{DETERMINATION OF COLOUR}

The colorimeter (Minolta Spectrophotometer CM-3500d, Japan) was used to measure the colour of all the samples. Calibration was done prior to measurements, using the white calibration plate on the target mask and distilled water in a quartz cell (CM-A97 $2 \mathrm{~mm}$ Cell, Japan). The results obtained were expressed in lightness $\left(\mathrm{L}^{*}\right)$, redness $\left(+a^{*}\right)$, greenness $\left(-a^{*}\right)$, yellowness $\left(+b^{*}\right)$ and blueness $\left(-b^{*}\right)$

To measure the colour of sugarcane juice upon storage, the extracted juice was placed in a glass bottles, labelled and left at room temperature for 30,60 and $90 \mathrm{~min}$, respectively. Sugarcane juice samples were then decanted into a small beaker after each storage time and the colour was measured using the spectrophotometer. 


\section{PREPARATION OF SUGARCANE JUICE FOR ANTIOXIDANT TEST}

Sugarcane juices obtained after extraction (with and without peel) with the addition of calamansi juice was poured into centrifuge bottles $(25 \mathrm{~mL})$ and centrifuged at $1556 \mathrm{~g}$ for $10 \mathrm{~min}$ (Khaw et al. 2016) using a centrifuge machine Model 4000, Kubota (Japan). The supernatant was then collected and used for antioxidant analysis.

\section{DETERMINATION OF TOTAL PHENOLIC CONTENT (TPhC)}

The method of Wolfe et al. (2003) was used to measure the total phenolic content of the samples. A volume of $0.125 \mathrm{~mL}$ of juice or standard solution was mixed with 0.5 $\mathrm{mL}$ of deionized water and $0.125 \mathrm{~mL}$ of Folin-Ciocalteu reagent and allowed to react for $6 \mathrm{~min}$. Approximately, $1.25 \mathrm{~mL}$ of $7 \%$ sodium carbonate solution was then added into the solution and the mixture was then diluted to $3 \mathrm{~mL}$ with deionized water. The absorbance of the mixture was measured at $760 \mathrm{~nm}$ using a UV-Vis spectrophotometer (UVmini-1240, Shimadzu Corp., Japan) after being allowed to react in a dark condition for $90 \mathrm{~min}$ at room temperature. The readings were then compared to a standard curve of prepared gallic acid solutions $(100,200,300,400 \& 500$ ppm) and results were expressed as milligrams of gallic acid equivalents per $100 \mathrm{~mL}$ of sugarcane juice. The analysis of $\mathrm{TPhC}$ was done in triplicate.

\section{DETERMINATION OF DPPH FREE RADICAL SCAVENGING ACTIVITY}

The DPPH free radical scavenging activity was conducted according to the method described by Duarte-Almeida et al. (2006). Methanolic solution of DPPH $(250 \mu \mathrm{L}, 0.5$ $\mathrm{mM}$ ) was added to $50 \mu \mathrm{L}$ of sample and was mixed well. The solution was then left at room temperature for $25 \mathrm{~min}$ and the absorbance was then measured at $517 \mathrm{~nm}$ using a microplate reader spectrophotometer $(\mathrm{EL} \times 800$, BioTek Instruments, USA). The analysis was done in triplicate and results were expressed as a percentage (\%) of DPPH inhibition using methanol as a control.

The percentage of DPPH radical scavenged was obtained by following the equation:

$$
\begin{aligned}
& \text { Scavenging effect } \\
& (\% \text { inhibition })
\end{aligned}=\frac{\begin{array}{l}
\text { (Methanol }(\mathrm{DPPH}) \\
\text { absorbance }- \text { sample absorbance }
\end{array}}{\text { Methanol }(\mathrm{DPPH}) \text { absorbance }} \times 100
$$

\section{DETERMINATION OF FERRIC REDUCING ANTIOXIDANT POWER (FRAP)}

Based on the method by Benzie and Strain (1996) and Mohammad Fadlinizal et al. (2010), the FRAP reagent was prepared with mixtures of $100 \mathrm{~mL}$ acetate buffer $300 \mathrm{mM}$ (pH3.6), $10 \mathrm{~mL}$ TPTZ (2,4,6-tri(22-pyridyI)-s-triazine), in

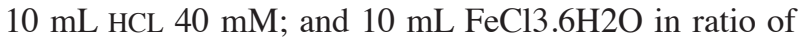
$10: 1: 1$. To perform the assay, $100 \mu \mathrm{L}$ of sugarcane were mixed with $1.8 \mathrm{~mL}$ of FRAP reagent and $100 \mu \mathrm{L}$ of distilled water. After incubation for $4 \mathrm{~min}$, the absorbance was measured at $593 \mathrm{~nm}$ using UV spectrophotometer.
The analysis was done in triplicates. A standard curve plotted using the FeSO $4.7 \mathrm{H} 2 \mathrm{O}$ linear regression equation was used to obtain the FRAP values of the samples. The FRAP value obtained was expressed as $\mu \mathrm{mol} \mathrm{Fe}^{2+}$ equivalents per $100 \mathrm{~mL}$ of juice.

\section{PREPARATION OF SUGARCANE JUICE FOR MICROBIOLOGICAL ANALYSES}

Serial dilution was carried out by mixing $1 \mathrm{~mL}$ of sample into $9 \mathrm{~mL}$ of peptone water in a universal bottle to make up $10^{-1}$ dilution (The peptone water is prepared by diluting 0.1 $\mathrm{g}$ of peptone powder to $100 \mathrm{~mL}$ of water and autoclaved ( HIRAYAMA Autoclaves HA-240MIV, Japan) at $121^{\circ} \mathrm{C}$ for 15 min. The dilution process was repeated until a $10^{-5}$ dilution sample was obtained.

\section{DETERMINATION OF TOTAL PLATE COUNT}

Pour plate method was chosen for the determination of total plate count (TPC). The total plate count was carried out according to the method described in FDA's Bacteriological Analytical Manual (Maturin \& Peeler 2001). One mL of each diluted sample was pipetted on to the petri dish, and $15 \mathrm{~mL}$ of molten Plate Count Agar was then poured into the petri dish. The samples and molten plate count agar were then gently mixed by swirling the petri dish clockwise and anticlockwise. After the agar solidified, the petri dish was then inverted and incubated at $37^{\circ} \mathrm{C}$ for $48 \mathrm{~h}$ in an incubator (Ambient-High Temperature Incubator Model Memmer, Germany). The results were expressed as colony forming units (CFU/mL).

\section{DETERMINATION OF YEAST AND MOULD COUNT}

For the total yeast and mould count similar pour plate technique was conducted as mentioned by Tournas et al. (2010) using Potato Dextrose Agar (PDA). One mL of each diluted sample is pipetted on to the petri dish and $15 \mathrm{~mL}$ of molten PDA was then poured into the petri dish containing the sugarcane juice. The samples were then mixed gently with the agar by swirling the petri dish clockwise and anticlockwise. After the agar solidified, the petri dish was incubated at $25 \pm 1^{\circ} \mathrm{C}$ for $72 \mathrm{~h}$ in an incubator. The results were expressed as colony forming units $(\mathrm{CFU} / \mathrm{mL})$.

\section{STATISTICAL ANALYSES}

All results were expressed as mean \pm standard deviation (SD). One and two-way analysis of variance (ANOVA) and independent sample t-test was used for analysing the data. Significant differences between samples were compared using Tukey's multiple comparison test at one and two-way analysis of variance (ANOVA) with a significance level of $p<0.05$. Statistical Package of Social Science (SPSS) version 22 (IBM Corporation, New York, USA) was used to perform the statistical analysis. 


\section{RESULTS AND DISCUSSION}

\section{PHYSICOCHEMICAL PROPERTIES OF FRESH SUGARCANE JUICE}

Table 1 shows the effects of calamansi juice at different concentration on the physicochemical properties such as $\mathrm{pH}$ value, titrable acidity (TA) and total soluble solids (TSS) on fresh sugarcane juice extracted with and without peel. Without addition of calamansi juice, the effects of the extraction with peel on the physicochemical properties of the sugarcane juice showed that there was no significant difference $(p>0.05)$ for the $\mathrm{pH}$ of the sugarcane juices. This can be concluded that, extraction with the peel did not bring any effects on the level of acidity of the sugarcane juice. However, when sugarcane juice is added with calamansi juice at $1.0 \%, 1.5 \%$ and $3.0 \%$, respectively, the $\mathrm{pH}$ value showed a decreasing trend in both sugarcane juices extracted with and without peel, which indicated an increase in acidity of the juice. The addition of $1.0 \%$ of calamansi juice was enough to give a significant $(p<0.05)$ increase in reading. This is expected as the $\mathrm{pH}$ of calamansi juice which is highly acidic (pH2.4) (Lee 2000) has the ability to decrease the $\mathrm{pH}$ value of sugarcane juice. By adding $1.0 \%$ of calamansi juice, the $\mathrm{pH}$ levels for both sugarcane juices extracted with and without peel decreased to less than 4.6. A decrease of $\mathrm{pH}$ of sugarcane juice has also been reported by Sangeeta et al. (2013) and Bhupinder et al. (1991) using anola and lemon juice, respectively. The reduction of $\mathrm{pH}$ to below 4.6 is important as it reduces microbial spoilage and promotes enzymatic stability as the enzyme polyphenol oxidase (PPO) is reported to have an optimal reaction at pH close to 7.2 (Kunitake et al. 2014).

Titratable acidity, a measurement of total acid concentration in sugarcane juice also showed no significant difference $(p>0.05)$ for sugarcane juice pressed with and without its peel. Increase in the concentration of calamansi juice had significantly increased the titratable acidity value, which attributable to the fact that as the concentration of calamansi juice is increased, the total acidity also increases. The result obtained was also in agreement with the findings of previous studies, which reported an increasing trend of titratable acidity with increasing citrus acid concentration such as anola juice (Sangeeta et al. 2013) and lemon juice (Bhupinder et al. 1991) in sugarcane juice.

The amount of solids dissolved in a sugarcane juice can be measured using Brix scale. The Brix value is considered equivalent to the percentage of sucrose in the juice. Generally, the Brix variation in sugarcane juice is in the range of $14^{\circ}$ to $22^{\circ}$ Brix (Abbas et al. 2013). Based on the results in Table 1, the sugarcane juice extraction with and without peel as well as addition of calamansi juice up to $3.0 \%$ had no significant $(p>0.05)$ effect on the TSS of sugarcane juice.

The lightness ( $\mathrm{L}^{*}$ value), redness (a* value) and yellowness $\left(b^{*}\right.$ value) colour of sugarcane juice after pressing with and without their peel showed significant difference $(p<0.05)$ (Table 1$)$. The result showed that the sugarcane juice obtained after pressed with peel had a higher $\mathrm{a}^{*}$ value (5.56) compared to sugarcane juice pressed without its peel (0.79). It can be concluded that the colour of sugarcane juice pressed with its peel is redder than the sugarcane juice pressed without its peel. This could be due to the peel of the sugarcane itself being dark reddish brown in colour which contributes to the colour of the sugarcane juices. The colours of the peel of sugarcanes are derived from two basic pigments: The red colour of anthocyanin and the green of chlorophyll (Panda 2011). The sugarcane with dark peel produces a darker juice colour. This is

TABLE 1. Effects of calamansi juice at different concentration on the physicochemical properties of fresh sugarcane juice with and without peel

\begin{tabular}{|c|c|c|c|c|c|}
\hline \multirow[b]{2}{*}{ Parameters } & \multirow[b]{2}{*}{ Treatment } & \multicolumn{4}{|c|}{ Calamansi juice concentration } \\
\hline & & $0.0 \%$ & $1.0 \%$ & $1.5 \%$ & $3.0 \%$ \\
\hline $\mathrm{pH}$ & $\begin{array}{c}\text { With peel } \\
\text { Without peel }\end{array}$ & $\begin{array}{l}5.28 \pm 0.01^{\mathrm{aA}} \\
5.25 \pm 0.01^{\mathrm{aA}}\end{array}$ & $\begin{array}{l}4.41 \pm 0.01^{\mathrm{bA}} \\
4.43 \pm 0.02^{\mathrm{bA}}\end{array}$ & $\begin{array}{l}4.18 \pm 0.01^{\mathrm{cA}} \\
4.15 \pm 0.02^{\mathrm{cA}}\end{array}$ & $\begin{array}{l}3.82 \pm 0.01^{\mathrm{dA}} \\
3.81 \pm 0.02^{\mathrm{dA}}\end{array}$ \\
\hline $\begin{array}{l}\text { Titratable acidity } \\
\text { (\% of citric acid) }\end{array}$ & $\begin{array}{c}\text { With peel } \\
\text { Without peel }\end{array}$ & $\begin{array}{l}0.08 \pm 0.01^{\mathrm{dA}} \\
0.07 \pm 0.01^{\mathrm{dA}}\end{array}$ & $\begin{array}{l}0.12 \pm 0.01^{\mathrm{cA}} \\
0.12 \pm 0.01^{\mathrm{cA}}\end{array}$ & $\begin{array}{l}0.16 \pm 0.01^{\mathrm{bA}} \\
0.17 \pm 0.01^{\mathrm{bA}}\end{array}$ & $\begin{array}{l}0.24 \pm 0.01^{\mathrm{aA}} \\
0.25 \pm 0.01^{\mathrm{aA}}\end{array}$ \\
\hline $\begin{array}{l}\text { Total Soluble Solid } \\
\qquad\left({ }^{\circ} \text { Brix }\right)\end{array}$ & $\begin{array}{c}\text { With peel } \\
\text { Without peel }\end{array}$ & $\begin{array}{l}19.8 \pm 0.06^{\mathrm{aA}} \\
19.9 \pm 0.06^{\mathrm{aA}}\end{array}$ & $\begin{array}{l}19.9 \pm 0.06^{\mathrm{aA}} \\
19.7 \pm 0.15^{\mathrm{aA}}\end{array}$ & $\begin{array}{c}19.9 \pm 0.1^{\mathrm{aA}} \\
19.8 \pm 0.25^{\mathrm{aA}}\end{array}$ & $\begin{array}{c}19.8 \pm 0.1^{\mathrm{aA}} \\
19.7 \pm 0.15^{\mathrm{aA}}\end{array}$ \\
\hline Colour & & & & & \\
\hline Lightness (L*) & $\begin{array}{c}\text { With peel } \\
\text { Without peel }\end{array}$ & $\begin{array}{l}55.15 \pm 0.23^{\mathrm{cB}} \\
67.25 \pm 0.02^{\mathrm{dA}}\end{array}$ & $\begin{array}{l}55.67 \pm 0.12^{\mathrm{bB}} \\
67.79 \pm 0.05^{\mathrm{cA}}\end{array}$ & $\begin{array}{c}55.82 \pm 0.60^{\mathrm{abB}} \\
68.30 \pm 0.08^{\mathrm{bA}}\end{array}$ & $\begin{array}{l}56.08 \pm 0.42^{\mathrm{aB}} \\
69.78 \pm 0.04^{\mathrm{aA}}\end{array}$ \\
\hline Redness $\left(a^{*}\right)$ & $\begin{array}{c}\text { With peel } \\
\text { Without peel }\end{array}$ & $\begin{array}{l}5.18 \pm 0.03^{\mathrm{bA}} \\
0.79 \pm 0.01^{\mathrm{dB}}\end{array}$ & $\begin{array}{l}5.19 \pm 0.06^{\mathrm{bA}} \\
1.31 \pm 0.02^{\mathrm{cA}}\end{array}$ & $\begin{array}{l}5.21 \pm 0.31^{\mathrm{bB}} \\
1.50 \pm 0.01^{\mathrm{bB}}\end{array}$ & $\begin{array}{l}5.56 \pm 0.11^{\mathrm{aA}} \\
1.74 \pm 0.01^{\mathrm{aB}}\end{array}$ \\
\hline Yellowness (b*) & $\begin{array}{c}\text { With peel } \\
\text { Without peel }\end{array}$ & $\begin{array}{c}45.7 \pm 0.13^{\mathrm{cA}} \\
34.43 \pm 0.02^{\mathrm{cB}}\end{array}$ & $\begin{array}{l}46.73 \pm 0.01^{\mathrm{bA}} \\
34.61 \pm 0.10^{\mathrm{bB}}\end{array}$ & $\begin{array}{l}46.88 \pm 0.03^{\mathrm{bB}} \\
34.71 \pm 0.04^{\mathrm{bA}}\end{array}$ & $\begin{array}{l}49.75 \pm 0.13^{\mathrm{aA}} \\
35.27 \pm 0.40^{\mathrm{aB}}\end{array}$ \\
\hline
\end{tabular}

A-B Mean value $(n=3) \pm$ standard deviation in a column by different superscript letters are significantly different

a-b Mean value $(n=3) \pm$ standard deviation in a row by different superscript letters are significantly different 
supported by the result which shows the lightness $\left(\mathrm{L}^{*}\right)$ value is significant $(p<0.05)$ higher in the sugarcane juice pressed without peel.

\section{COLOUR PROPERTIES OF FRESH SUGARCANE JUICE AT DIFFERENT STORAGE TIME}

Table 2 presents CIE Lab colour parameters in relation to fresh sugarcane juice at different storage time of 30 , 60 and $90 \mathrm{~min}$. As storage time increases, result shows a decreasing $\mathrm{L}^{*}$ value (lightness) and significantly difference $(p<0.05)$ in both sugarcane juice obtained after extraction with and without peel. This might be due to the increasing redness value $\mathrm{a}^{*}$ which indicates that browning has occurred in the sugarcane juices.

Darkening or browning of sugarcane juice happens due to the formation of brown pigments produced by enzymatic and non-enzymatic reactions. Non-enzymatic reaction includes melanoidins formed from sugar amino acid reaction via the Maillard reaction and thermal degradation as well as condensation reaction of sugar (caramelization). The increase in $a^{*}$ value with increasing storage time (Table 2) is probably due to enzymatic reaction as no heat is involved. When the juice is extracted, the exposure to the air and oxygen initiate enzymatic browning caused by the activity of peroxidase (POD) and polyphenol oxidase (PPO) (Qudsieh et al. 2002).

Through data from Table 1, the addition of calamansi juice gives a significant difference $(p<0.05)$ on lightness $\left(\mathrm{L}^{*}\right)$, redness $\left(\mathrm{a}^{*}\right)$ and yellowness $\left(\mathrm{b}^{*}\right)$ on the sugarcane extracted with and without peel. As the addition of calamansi juice increased, the $\mathrm{L}^{*}$ and $\mathrm{b}^{*}$ value had significantly increased, indicating an increase of lightness and yellowness in both sugarcane extracted with and without peel. There is significant $(p<0.05)$ on $\mathrm{a}^{*}$ value (redness) as addition of calamansi juice increases. The colour results are supported by previous study reports that in acidic medium, magnesium that exists in the chlorophyll ring in the sugarcane juice is replaced by two hydrogen ions and green chlorophylls are converted to the olive brown pheophytins (Mangos \& Berger 1997; Van Boekel 1991). In the case of sugarcane juice, the greater the amount of acid added, the lesser the green colour; thus acquiring a yellowish green tone (Prati \& Moretti 2010).

\section{ANTIOXIDANT PROPERTIES OF FRESH SUGARCANE JUICE}

Table 3 shows the effects of calamansi juice at different concentrations on the antioxidant properties of fresh sugarcane juice obtained after extraction with and without peel. For total phenolic content, DPPH scavenging activity and also FRAP assay, there was significant difference $(p<0.05)$ on sugarcane pressed with and without peel. Sugarcane juice pressed with peel showed higher antioxidant properties value compared to sugarcane juice pressed without its peel in all the antioxidant tests. The data obtained reflects that the peel of the sugarcane plays a significant role in the antioxidant properties of the sugarcane juice and values obtained were accordance to a study conducted by Wolfe et al. (2003) on apples, which reported that the peel of the fruit had higher phenolic content than the flesh of the fruit. In sugarcane, the juice pressed with peel contained coloured pigments which contributed to the phenolic compounds (Rupa \& Asokan 2008). Pallavi et al. (2012) also stated that sugarcane peel could be evaluated as a main source of anthocyanin, flavonoids and polyphenol antioxidant.

$\mathrm{TPhC}$ of sugarcane juice pressed with and without peel after addition of calamansi juice up to $3.0 \%$ has managed to increase the phenolic content; however, it had no significant effect ( $p>0.05)$. Cheong et al. (2012) reported that Malaysian grown calamansi contained lower amount of phenolic acid compared to calamansi fruit grown in other Southeast Asian countries like Philippines and Vietnam. This could be the reason why the calamansi juice added did not give enough effect towards significantly increasing the phenolic content of the sugarcane juice.

DPPH, a dark crystalline powder is composed of stable free-radical molecules and has been widely used to test free radical scavenging ability. DPPH solution which is originally purple turns yellow when it is reduced by antioxidants available in the sugarcane juice (Abbas et al. (2012). Based on Table 3, it was observed that increasing calamansi juice addition, increased the DPPH scavenging activity of the sugarcane juice pressed with and without peel. Sugarcane juice pressed with peel at the addition of $3.0 \%$ calamansi juice showed the highest scavenging activity (73.34\% inhibition) followed by sugarcane juice pressed with peel at the addition of $1.5 \%$ calamansi juice

TABLE 2. CIE Lab colour parameters in relation to fresh sugarcane juice at different storage time

\begin{tabular}{ccccc}
\hline & & \multicolumn{3}{c}{ Storage time (min) } \\
\cline { 3 - 5 } Colour parameter & Treatment & 30 & 60 & 90 \\
\hline L $^{*}$ (Lightness) & With peel & $52.33 \pm 0.01^{\mathrm{aB}}$ & $52.26 \pm 0.02^{\mathrm{bB}}$ & $51.88 \pm 0.21^{\mathrm{cB}}$ \\
& Without peel & $68.88 \pm 0.05^{\mathrm{aA}}$ & $68.29 \pm 0.12^{\mathrm{bA}}$ & $68.01 \pm 0.07^{\mathrm{cA}}$ \\
$\mathrm{a}^{*}$ (Redness) & With peel & $6.78 \pm 0.01^{\mathrm{bA}}$ & $6.83 \pm 0.31^{\mathrm{bA}}$ & $7.06 \pm 0.25^{\mathrm{aA}}$ \\
& Without peel & $1.18 \pm 0.01^{\mathrm{bB}}$ & $1.20 \pm 0.01^{\mathrm{bB}}$ & $1.24 \pm 0.02^{\mathrm{aB}}$ \\
$\mathrm{b}^{*}$ (Yellowness) & With peel & $52.91 \pm 0.15^{\mathrm{aA}}$ & $52.89 \pm 0.1^{\mathrm{aA}}$ & $52.65 \pm 0.17^{\mathrm{bA}}$ \\
& Without peel & $41.51 \pm 0.25^{\mathrm{aB}}$ & $41.37 \pm 0.16^{\mathrm{abB}}$ & $40.95 \pm 0.22^{\mathrm{bB}}$ \\
\hline
\end{tabular}

A-B Mean value $(n=3) \pm$ standard deviation in a column by different superscript letters are significantly different

${ }^{a-b}$ Mean value $(n=3) \pm$ standard deviation in a row by different superscript letters are significantly different 
TABLE 3. Effects of calamansi juice at different concentration on the antioxidant properties of fresh sugarcane juice with and without peel

\begin{tabular}{cccccc}
\hline & & \multicolumn{4}{c}{ Calamansi juice concentration } \\
\cline { 3 - 5 } Parameters & Treatment & $0.0 \%$ & $1.0 \%$ & $1.5 \%$ & $3.0 \%$ \\
\hline Total phenolic content & With peel & $35.19 \pm 0.51^{\mathrm{aA}}$ & $35.25 \pm 0.18^{\mathrm{aA}}$ & $35.33 \pm 0.06^{\mathrm{aA}}$ & $35.48 \pm 0.14^{\mathrm{aA}}$ \\
$(\mathrm{mg} \mathrm{GAE} / 100 \mathrm{~mL}$ juice$)$ & Without peel & $28.83 \pm 0.11^{\mathrm{aB}}$ & $29.43 \pm 0.03^{\mathrm{aB}}$ & $29.49 \pm 0.14^{\mathrm{aB}}$ & $30.80 \pm 0.08^{\mathrm{aB}}$ \\
DPPH & With peel & $70.06 \pm 1.33^{\mathrm{bA}}$ & $71.93 \pm 0.69^{\mathrm{abA}}$ & $72.20 \pm 0.49^{\mathrm{abA}}$ & $73.34 \pm 1.44^{\mathrm{aA}}$ \\
$(\%$ Inhibition $)$ & Without peel & $56.73 \pm 0.18^{\mathrm{aB}}$ & $58.69 \pm 0.68^{\mathrm{cB}}$ & $61.57 \pm 0.20^{\mathrm{bB}}$ & $64.54 \pm 0.43^{\mathrm{aB}}$ \\
FRAP Value & With peel & $386.03 \pm 2.08^{\mathrm{bA}}$ & $392.03 \pm 3.51^{\mathrm{bA}}$ & $402.03 \pm 4.04^{\mathrm{abA}}$ & $412.03 \pm 11.02^{\mathrm{aA}}$ \\
$\left(\mu \mathrm{mol} \mathrm{Fe}{ }^{2+}\right.$ Eq/100 $\left.\mathrm{mL}\right)$ & Without peel & $286.03 \pm 3.79^{\mathrm{bB}}$ & $293.37 \pm 7.77^{\mathrm{bB}}$ & $305.37 \pm 8.89^{\mathrm{abB}}$ & $322.03 \pm 16.7^{\mathrm{aB}}$ \\
\hline
\end{tabular}

A-B Mean value $(n=3) \pm$ standard deviation in a column by different superscript letters are significantly different

a-b Mean value $(n=3) \pm$ standard deviation in a row by different superscript letters are significantly different

(72.20\% inhibition). In addition, calamansi juice added in the sugarcane juice was also found to contain organic acids such as ascorbic acid (Cheong et al. 2012). Ascorbic acid or also known as vitamin $\mathrm{C}$ is a famous antioxidant due to its ability as an electron donor and therefore a reducing agent.

When ascorbic acid takes part in radical scavenging activity, it donates an electron to the free radical species (Pereira et al. 2009). Ascorbic acid then exists as a less reactive ascorbyl free radical which then can be reduced back to ascorbic acid by reducing agents (Seabra et al. 2006). Thus, the increase of scavenging activity could be contributed by the ascorbic acid present in the calamansi juice added. The results obtained were also in accordance to previous studies conducted on sugarcane juice (Abbas et al. 2013; Duarte-Almeida et al. 2006; Vila et al. 2008). It is also noted that for sugarcane pressed with peel there was only a significant difference $(p<0.05)$ between $0.0 \%$ and $3.0 \%$ calamansi juice addition; meanwhile for sugarcane pressed without peel there was significant difference after $1.0 \%$ addition of calamansi juice. Anthocyanins found on the peel of sugarcane might be a bigger contributor to the antioxidant activity compared to the ascorbic acid, therefore causing ascorbic acid to have less significant effect on the sugarcane juice sample pressed with peel.

Table 3 also shows the FRAP values for sugarcane pressed with and without peel after calamansi juice addition at different concentrations. The FRAP assay uses antioxidants as a reducing agent to reduce an easily reducible oxidant $\mathrm{Fe}(\mathrm{III})$. Fe(III) complex once reduced by the antioxidant to $\mathrm{Fe}(\mathrm{II})$, a blue complex is formed which can be detected and measured using a spectrophotometer. In the study, as the concentration of calamansi juice increases, the FRAP value of the sugarcane also increases in sugarcane juice pressed with and without peel. The highest FRAP value for sugarcane pressed with peel and without peel is after the addition of $3.0 \%$ of calamansi juice at $412.03 \mu \mathrm{mol} \mathrm{Fe} e^{2+}$ eq/100 $\mathrm{mL}$ and $322.03 \mu \mathrm{mol} \mathrm{Fe}{ }^{2+}$ eq/100 $\mathrm{mL}$, respectively. The reducing ability of Fe(III) was generally linked to the presence of reductones; reductones contribute to the antioxidant activity by breaking the free radical chain by donating a hydrogen atom. The increase in the FRAP value could be attributed to the organic acid found in calamansi juice added. Calamansi juice is made up of $5.62 \%$ of organic acid with citric acid being its biggest contributor followed by ascorbic acid (Cheong et al. 2012). Citric acid is reported to strengthen the action of primary antioxidants such as ascorbic acid by working together or by action of metal complexes that catalysis self-oxidation reaction (Butnariu \& Grozea 2012; Singh \& Rajini 2008).

\section{MICROBIOLOGICAL PROPERTIES OF FRESH SUGARCANE JUICE}

Table 4 reports the effects of calamansi juice at different concentrations on the microbiological properties of fresh sugarcane juice obtained after extraction with and without peel. The total plate count of the sugarcane juice pressed with peel, with and without addition of calamansi juice was in the range of $2.02 \times 10^{5}-1.40 \times 10^{5} \mathrm{CFU} / \mathrm{mL}$, which is higher than the sugarcane juice pressed without its peel which was in the range of $1.99 \times 10^{4}-1.57 \times 10^{4}$ $\mathrm{CFU} / \mathrm{mL}$. There is unfortunately no information on the acceptable microbial limit for sugarcane juice as there is no microbiological standard for total plate count, yeast and mould count on fresh sugarcane juice in The Malaysian Food Regulation 1985. There is also no information on the limit in the Brazilian Food Legislation, although Brazil is one of the biggest producer of sugarcane. However, result from Table 4 shows higher count than the maximum bacterial load permitted by the Gulf Standards (2000) which is $1.0 \times 10^{4}$ per $\mathrm{mL}$ of juice consumed. Even so, both values obtained in the study were lower than the value reported by Misra et al. (2017) which was in the ranged of $10^{6}$ to $10^{9} \mathrm{CFU} / \mathrm{mL}$ of microorganisms in sugarcane juice. Silva et al. (2016) reported that moulds and yeasts are commonly found in freshly pressed sugarcane juice and a study by Milintawisamai et al. (2009) reported that in sugarcane juice, the microbial contamination found is mainly yeast. Table 4 shows that, yeast and mould count from sugarcane juice pressed was in range from $10^{5}-10^{4}$ $\mathrm{CFU} / \mathrm{mL}$ for sugarcane juice pressed with peel and $10^{4}$ $\mathrm{CFU} / \mathrm{mL}$ for sugarcane juice without peel. Highest yeast and mould count was from sugarcane juice pressed with its peel, $0.0 \%$ calamansi juice addition, at $1.05 \times 10^{5} \mathrm{CFU} /$ $\mathrm{mL}$. Although the value obtained was lower in the study, it is accordance to Afridi et al. (2015) which obtained 4.0 
TABLE 4. Effects of calamansi juice at different concentration on the microbiological properties of fresh sugarcane juice with and without peel

\begin{tabular}{cccccc}
\hline \multirow{2}{*}{ Parameters } & & \multicolumn{4}{c}{ Calamansi juice concentration } \\
\cline { 3 - 6 } & Treatment & $0.0 \%$ & $1.0 \%$ & $1.5 \%$ & $3.0 \%$ \\
\hline Total plate count $(\mathrm{CFU} / \mathrm{mL})$ & With peel & $2.02 \times 10^{5 \mathrm{Aa}}$ & $1.92 \times 10^{5 \mathrm{Ab}}$ & $1.79 \times 10^{5 \mathrm{Bc}}$ & $1.40 \times 10^{5 \mathrm{Bd}}$ \\
& Without peel & $1.99 \times 10^{4 \mathrm{Ba}}$ & $1.82 \times 10^{4 \mathrm{Ba}}$ & $1.81 \times 10^{4 \mathrm{Aa}}$ & $1.57 \times 10^{4 \mathrm{Ab}}$ \\
& With peel & $1.05 \times 10^{5 \mathrm{Aa}}$ & $9.55 \times 10^{4 \mathrm{Aab}}$ & $8.68 \times 10^{4 \mathrm{Ab}}$ & $6.38 \times 10^{4 \mathrm{Ac}}$ \\
Yeast and mould count $(\mathrm{CFU} / \mathrm{mL})$ & Without peel & $2.17 \times 10^{4 \mathrm{Ba}}$ & $2.07 \times 10^{4 \mathrm{Bab}}$ & $1.97 \times 10^{4 \mathrm{Bb}}$ & $1.62 \times 10^{4 \mathrm{Bc}}$ \\
\hline
\end{tabular}

${ }^{A-B}$ Mean value in a column by different superscript letters are significantly different

a-b Mean value in a row by different superscript letters are significantly different

$\times 10^{5} \mathrm{CFU} / \mathrm{mL}$ of yeast and mould in fresh sugarcane juice sold in Pakistan.

The sugarcane juice pressed with its peeled showed a higher $\mathrm{CFU} / \mathrm{mL}$ in both total plate count and yeast and mould count as compared to sugarcane juice pressed without its peel. Since sugarcane is a plant that grows from the ground, bacteria and microbes commonly found in the soil might adhere to the peel. Mahale et al. (2008) also reported that most fruit surfaces contain bacterial counts of $1 \times 10^{5} \mathrm{CFU} / \mathrm{cm}^{2}$. Hence, if the peel and surface are not cleaned thoroughly and the juice is prepared poorly and unhygienically, the juice prepared will have a higher microbial count.

The result also showed that calamansi juice has the ability to reduce yeast and moulds as well as total plate counts of sugarcane juice (Table 4). This is predicted as citrus fruit is commonly known for its antimicrobial properties. In this study, the total plate count as well as the yeast and mould count of the sugarcane juice decrease as the concentration of calamansi juice increases. The addition of calamansi juice resulted in lowering the $\mathrm{pH}$ of the sugarcane juice, which then gave a preservative action by creating an unfavarouble growing condition for the microorganisms (Sangeeta et al. 2013). Even so, Leuconostoc bacteria, the main microorganism found in sugarcane is acid resistance. Therefore, a heat treatment has to be paired with acidification to further reduce this bacteria. According to Eggleston (2002), the acid resistance Leuconostoc bacteria can be reduced through pasteurisation treatment. However, if pasteurisation is not able to be conducted by roadside sugarcane juice vendors, the other option is they could peel off the sugarcane and acidify it. The results from Table 4 shows total plate count and yeast and mould count were lower on sugarcane juice pressed without its peel. Sugarcane juice pressed without peel with addition of calamansi juice at $1.0 \%$ also showed to have lower total plate count and yeast and mould count compared to the sugarcane juice pressed with its peel with $3.0 \%$ addition of calamansi juice.

\section{CONCLUSION}

The result showed that the sugarcane juiced without its peel does not give any effect on the level of acidity and also the total soluble solid (TSS) of the juice. It is observed that sugarcane pressed without its peel produced juice which has a lighter and greener colour compared to sugarcane juice pressed with peel. From visual observation, removing the peel of sugarcane, the juice obtained is less turbid and low in sediments. Although the sugarcane pressed with its peel exhibited higher antioxidant values than the sugarcane juice pressed without its peel, the latter had a lower microbial and yeast and mould count. The addition of calamansi juice to the sugarcane juice yield a significant effect on both the $\mathrm{pH}$ and titratable acidity of the samples. The acidic medium decreased the green colour of the sugarcane juice pressed with and without its peel. As the calamansi juice is added, the sugarcane juice acquired a more yellowish tone. Furthermore, addition of calamansi juice also significantly increased DPPH scavenging activity and FRAP values. Finally, the addition of calamansi juice to sugarcane juice pressed without its peel produced a juice with a lower bacterial and yeast and mould count. This experiment is carried out to gain information regarding sugarcane juice that can be helpful towards the juice and food industry in Malaysia as the data can be used to help further improve the ways on making local beverage safer and healthier.

\section{ACKNOWLEDGEMENTS}

The authors would like to thank Universiti Sains Malaysia for providing the laboratory facilities and funds for this research through the Research University Grant (1001. PTEKIND.811338).

\section{REFERENCES}

Abbas, S., Sabir, S., Ahmad, S., Zulfiqar, A., Wajid, A., Hamid, A., Batool, A. \& Abbas, M.R. 2013. Antioxidant activity and biochemical variation among juices of different genotypes of sugarcane. Italian Journal of Food 25: 453-458.

Afridi, M., Ali, J., Hussain, A., Ziarurahman, S., Paracha, G.M.S., Rahman, I.U. \& Hassan, S. 2015. Microbiological quality evaluation, preservation and shelf life studies of sugar cane juices sold in Peshawar City, Khyber Pakhtunkhwa-Pakistan. American-Eurasian J.Agric. \& Environ. Sci. 15(4): 485-489.

Butnariu, M. \& Grozea, I. 2012. Antioxidant (antiradical) compounds. Journal of Bioequivalence \& Bioavailability 4: xvii-xix. doi: 10.4172/jbb.10000e18. 
Bhupinder, K., Sharma, K.P. \& Harinder, K. 1991. Studies on the development and storage stability for ready to serve bottled sugarcane juice. International Journal of Tropical Agriculture 9(2): 128-134

Chauhan, O., Singh, D., Tyagi, S. \& Balyan, D. 2002. Studies on preservation of sugarcane juice. International Journal of Food Properties 5(1): 217-229.

Cheong, M.W., Zhu, D., Sng, J., Liu, S.Q., Zhou, W. \& Curran, P. 2012. Characterisation of calamansi (Citrus microcarpa). Part II: Volatiles, physicochemical properties and non-volatiles in the juice. Food Chemistry 134(2): 696-703.

Eggleston, G. 2002. Deterioration of cane juice-sources and indicators. Food Chemistry 78(1): 95-103.

Gulf Standards. 2000. Microbiological Criteria for Foodstuffs. Riyadh, Saudi Arabia: GCC.

Khare, A., Behari Lal, D.A., Singh, A. \& Singh, A.P. 2012. Shelflife enhancement of sugarcane juice. Croatian Journal of Food Technology, Biotechnology and Nutrition 7(3-4): 179-183.

Khaw, H., Haron, H. \& Chan, B. 2016. Comparison of total phenolic contents (TPC) and antioxidant activities of fresh fruit juices, commercial 100\% fruit juices and fruit drinks. Sains Malaysiana 45(9): 1319-1327.

Kunitake, M., Ditchfield, C., Silva, C. \& Petrus, R. 2014. Effect of pasteurization temperature on stability of an acidified sugarcane juice beverage. Ciencia e Agrotecnologia 38(6): 554-561.

Lee, S.Y. 2000. Physico-chemical characteristics of calamansi juice, agglomerate and drink. Journal of Tropical Agriculture and Food Science 28(2): 183-188.

Mahale, D.P., Khade, R.G. \& Vaidya, V.K. 2008. Microbiological analysis of street vended fruit juices from Mumbai City, India. Internet Journal of Food Safety 10(2008): 31-34.

Mangos, T.J. \& Berger, R.G. 1997. Determination of major chlorophyll degradation products. R.Z. Lebensm. Unters. Forsch. 204(5): 345-350.

Mao, L.C., Xu, Y.Q. \& Que, F. 2007. Maintaining the quality of sugarcane juice with blanching. Food Chemistry 104(20): 740-745.

Maturin, L. \& Peeler, J. 2001. Laboratory Methods - BAM: Aerobic Plate Count. U.S Food And Drug Administration: https://www.fda.gov/Food/FoodScienceResearch/ LaboratoryMethods/ucm063346.htm. Accessed on 17 September 2017.

Milintawisamai, N., Niamsanit, S., Ngasan, C., Pliansinchai, U.\& Weerathaworn, P. 2009. Dextran producing microorganisms from Mitr Phuvening Sugar Factory, Thailand. Sugar Tech. 11(2): 196-199.

Misra, V., Mall, A., Pathak, A., Solomon, S. \& Kishor, R. 2017. Microorganisms affecting post-harvest sucrose losses in sugarcane. International Journal of Current Microbiology and Applied Sciences 6(7): 2554-2566.

Panda, H. 2011. The Complete Book on Sugarcane Processing and By-Products of Molasses (with Analysis of Sugar, Syrup and Molasses). Asia Pacific Business Press Inc.
Prati, P. \& Moretti, R.H. 2010. Study of clarification process of sugar cane juice for consumption. Food Science and Technology (Campinas) 30(3): 776-783.

Qudsieh, H., Yusof, S., Osman, A. \& Rahman, R. 2002. Effect of maturity on chlorophyll, tannin, color and polyphenol oxidase (PPO) activity of sugarcane juice (Saccharum officinarum var, Yellow Cane). Journal of Agricultural and Food Chemistry 50(6): 1615-1618.

Sangeeta, Hathan, B.S. \& Khatkar, B.S. 2013. Studies on stability of sugarcane juice blended with anola juice at refrigerated and room temperature. International Journal of Agriculture and Food Science Technology 4(10): 1027-1036.

Sarkar, S., Roy, D.K., Alomoni, Siddik, M.A., Das, K. \& Rahman, M.J. 2015. Effect of chemical preservatives and storage conditions on the nutritional quality of tomato pulp. American Journal of Food and Nutrition 3(4): 90-100.

Silva, C., Gallo, F., Bomdespacho, L., Kushida, M. \& Petrus, R. 2016. Sugarcane juice processing: Microbiological monitoring. Journal of Food Processing \& Technology 7: 607. doi:10.4172/2157-7110.1000607.

Singh, N. \& Rajini, P. 2008. Antioxidant-mediated protective effect of potato peels extract in erythrocytes against oxidative damage. Chemico-Biological Interactions 173(2): 97-104.

Siti, R. \& Baharuddin, B. 1994. Tebu kuning-Varieti tebu jus. Telcnologi Pelbagai Tanaman, Jilid 10.

Stone, H. \& Sidell, J. 1985. Sensory Evaluation Practices. London: Academic Press.

Tournas, V., Stack, M., Mislivec, P., Koch, H. \& Bandler, R. 2001, April. Laboratory Methods - BAM: Yeasts, molds and mycotoxins. https://www.fda.gov/Food/ FoodScienceResearch/LaboratoryMethods/ucm071435. htm. Accessed on 18 September 2017.

Van Boekel, M. 1991. Testing of kinetic models: Usefulness of the multiresponse approach as applied to chlorophyll degradation in foods. Food Research International 32(4): 261-269.

Wolfe, K., Wu, X. \& Liu, R.H. 2003. Antioxidant activity of apple peels. Journal of Agricultural and Food Chemistry 51(3): 609-614.

Yusof, S., Shian, L.S. \& Osman, A. 2000. Changes in quality of sugar-cane juice upon delayed extraction and storage. Food Chemistry 68(4): 395-401.

School of Industrial Technology

Food Science and Technology Division

Universiti Sains Malaysia

11800 USM Penang, Pulai Pinang

Malaysia

*Corresponding author; email: maizura@usm.my

Received: 27 February 2018

Accepted: 16 May 2018 